\title{
塗膜防水層下のコンクリートひび割れ部分の炭酸化 CARBONATION OF CRACKED ZONE IN CONCRETE COATED BY WATERPROOFING MEMBRANE
}

\author{
塚 越雅 幸*1, 宮内博之*2, 田中享二*3 \\ Masayuki TSUKAGOSHI, Hiroyuki MIYAUCHI and Kyoji TANAKA
}

\begin{abstract}
The purpose of this elaboration is to investigate the carbonation resistance of waterproofing membranes applied to the concrete surface, particularly the cracked zone of the underlying concrete. The considered parameters were, the width of the crack in the concrete, the presence or absence of the waterproofing membrane, and the membrane thickness. Mortar prisms shaped specimens were coated by two types of the fluid waterproofing membrane. The prisms were cracked by bending and then exposed to an accelerated carbonation environment with an atmosphere of $10 \%$ carbon dioxide. After 1 year of exposure in this environment, the depth of carbonation was measured. Carbonation areas were observed along the cracks of the specimens with thin coatings along the wide cracks. Furthermore, a numerical simulation method was developed on the basis of diffusion theory and the carbonation at the cracked area of the concrete was simulated.
\end{abstract}

Keywords : Waterproofing membrane, Concrete, Crack, Carbonation, Durability 防水層、コンクリート、ひび割れ、炭酸化、耐久性

\section{1.はじめに}

コンクリートの炭酸化抑制には、仕上げ塗り材や防水材料の塗布 も有効であり、最近多く利用されるようになってきている。元来コ ンクリートは、それ自身である程度の耐久性をもつ材料ではあるが、 近年、建築物への長寿命化が求められていることから、それに対す る一つの手段としてこれら塗膜系材料の炭酸ガスの遮断性能が下 地コンクリートの炭酸化防止に対し期待されている。そして、実際 これらの材料の炭酸化抑止効果に関するデータも多く紹介されて いる。

しかし、鉄筋コンクリート建物では、ひび割れの発生を完全に抑 制する事は難しいとされている。従ってひび割れ部分でも炭酸化抑 制効果が保証されなければ、真の意味でこれら材料が有効であるこ とにはならない。これら材料はコンクリートひび割れ直上で引っ張 られると、局部的に皮膜が薄くなり、炭酸ガスの遮断性能の低下が 縠念されるからである。現在はその点についての注意がほとんど払 われていない。この材料の有効性を示すためには、ひび割れ部分で の炭酸化抑制効果のデータの提示が不可欠である。

一般に塗膜系材料の、下地コンクリートのひび割れ抵抗性はその 厚さにほぼ比例する。従って厚いものがより安全である。そのため 本研究ではまず、塗膜系材料の中で比較的厚塗りの期待される塗膜
称防水層を対象として、ひび割れの発生したコンクリートに対し、 どの程度の炭酸化抑止効果が期待されるのかを検討した。

\section{2. 既往の研究}

従来からコンクリートでは、ひび割れに沿って炭酸化が内部まで 進行することは良く知られており、研究例 ${ }^{1-3)}$ も多い。一方各種有 機質系仕上げ材料のコンクリート炭酸化抑止効果についても研究 がなされるようになっており、多種類の市販の材料について、その 効果も報告されている ${ }^{4-6)}$ 。合わせて理論面での研究も進み、福島 等 ${ }^{7-8)}$ は、数値計算により仕上げ材の効果を定量的に評価している。 しかし、これらはすべてひび割れのないコンクリートの健全部分に 対してのみの研究であり、実際の使用上で問題となるひび割れ部分 での炭酸化抑止効果については、筆者等の知る範囲ではほとんど検 討されていない。

\section{3. 防水層の炭酸化抑制性能におよぼす塗膜厚さと下地ひび割れ幅 の影響に関する実験}

\section{1 試験体 \\ (1) 下地}

試験体について、下地のひび割れ部を対象として観察を行うこと
*1 東京工業大学 大学院生・工修

*2 東京工業大学建築物理研究センタ一 助手・博士 (工学)

*3 東京工業大学建築物理研究センター 教授・工博
Graduate Student, Tokyo Institute of Technology, M. Eng.

Res. Assoc., Structural Engineering Research Center, Tokyo Institute of Technology, Dr. Eng.

Prof., Structural Engineering Research Center, Tokyo Institute of Technology, Dr. Eng. 
を目的としていること、また、ひび割れ部における炭酸化の観察の しやすさを考慮して、コンクリートの代用として、 $10 \mathrm{~cm} \times 10 \mathrm{~cm} \times$ $40 \mathrm{~cm}$ のモルタル角柱を用いた。この調合表を表 1 に示す。これを 曲げ試験により試験体にひび割れを生じさせなければならないが、 ひび割れ幅の制御を確実にするために、その点に工夫を加えた試験 体を作成した。すなわち図 1 に示すように、ひび割れを生じさせよ うとする試験体の上方に、ビニルチューブの中に入れた鉄筋とモル タルとの付着を防止した $4 \mathrm{~mm} \phi$ のねじ付き鉄筋を 2 本配した。この 鉄筋の両端をナットの回転によりひび割れ幅を制御できるように した。試験体下方は過度のひび割れ進展防止と試験体破損防止のた めに、6 $\mathrm{mm} \phi$ の異型鉄筋を 2 本設置した。なお試験体は打ち込み後、 3 ヶ月間水中養生し、十分に水和反応させた後、さらに実験室内で 2 ケ月間乾燥させた。

（2）防水層部分

試料として用いた塗膜系防水層は、表 2 に示守通常の防水工事に 用いられる市販のウレタンゴム系塗膜防水層とアクリルゴム系防 水層を用いた。ひび割れ抵抗性は塗膜厚さとも密接に関係するため、 $0.3 \mathrm{~mm}, 0.5 \mathrm{~mm}, 1 \mathrm{~mm}, 3 \mathrm{~mm}$ (但しアクリルゴム系塗膜防水層は標準仕 様に合わせて、厚さ $3 \mathrm{~mm}$ を $2 \mathrm{~mm}$ とした）の 4 段階とした。なお、一 般の防水工事においては表面保護層としてトップコートが施工さ れる。そのため、表面にトップコートを約 $0.1 \mathrm{~mm}\left(200 \mathrm{~g} / \mathrm{m}^{2}\right)$ の厚さで 施工した。

防水層の施工については、各仕様に基づき室温環境下で塗布した。 その後、防水層を十分硬化させるため、実験室内で 1 ヶ月間養生し た。なお、次の作業におけるひび割れの作成過程で、ひび割れ幅の 制御のために防水層施工面でのひび割れ幅を直接測定する必要が ある。その際モルタル表面を一部露出させる必要があるため、防水 層を両端部から幅 $10 \mathrm{~mm}$ 程度ビニルテープでマスキングをした。

（3）ひび割れの作成

油圧式圧縮試験機を利用して、3 点曲げにより防水層裏面の下地 モルタルにひび割れを生じさせた。加力直前に、ビニルテープで下 地から絶縁していた防水層部分を除去し、モルタル面を露出させた。 また、加力時にクラックスケールでひび割れ幅を測定しながら行っ た。所定のひび割机幅になった時点で、各種厚さのステンレスのス ペーサーをひび割れ内に㨂入し、ねじの付いた鉄筋を固定用ナット で締めることで、ひび割れ幅を保持した。

ひびわれ幅は $0.5 \mathrm{~mm}, 1 \mathrm{~mm}, 3 \mathrm{~mm}$ の 3 段階とした。なお、ここで作 製したひび割れ深さは、ひび割れ幅 $0.5 \mathrm{~mm}$ の場合 $85 \mathrm{~mm} 、 1 \mathrm{~mm}$ の場合 $90 \mathrm{~mm} 、 3 \mathrm{~mm}$ の場合 $95 \mathrm{~mm}$ 程度となった。ひび割れ幅を固定した後、ひ び割れ面を再度テープによりマスキングし、さらに防水層面以外の 面をエポキシ樹脂でコーティングし、外気との接触を完全に遮断し た。これら試験体作成の一連の過程を図 2 に示す。表 3 にこのよう な組み合わせで用意された全試験体の種類を示す。

\section{2 促進中性化試験(促進炭酸化試験) と炭酸化領域の測定}

エポキシ樹脂の硬化後、試験体を直ちに試験槽（ $\mathrm{CO}_{2}$ 濃度 $10 \pm$ $0.5 \%$ 、温度 $20 \pm 2{ }^{\circ} \mathrm{C}$ 、湿度 $60 \pm 10 \%$ R. H. ）に暴露した。暴露期間は 1 年間とした。所定の時間経過後、後の作業におうり試験体破損防止 のため、まずマスキング部分のエポキシコーティングを除去し、ひ び割れ部分を露出させた。そこからエポキシ樹脂をひび割れ内部に 注入し、ひび割れ部分を固定した。エポキシ樹脂硬化後、試験体を
表1 モルタル調合

\begin{tabular}{|c|c|c|c|c|c|}
\hline \multirow{2}{*}{$\begin{array}{c}W / C \\
(\%)\end{array}$} & \multicolumn{3}{|c|}{ 単位量 $\left(\mathrm{kg} / \mathrm{m}^{3}\right)$} & \multirow{2}{*}{$\begin{array}{c}\text { 空気量 } \\
(\%)\end{array}$} & \multirow{2}{*}{$\begin{array}{l}\text { フேー } \\
(\mathrm{cm})\end{array}$} \\
\hline & 水*1 & セメント*2 & 細骨材*3 & & \\
\hline 60 & 278 & 463 & 1389 & 1.0 & 17 \\
\hline
\end{tabular}

$* 1:$ 水道水、 $* 2$ : 普通ポルトランドセメント $\left(3.16 \mathrm{~g} / \mathrm{cm}^{3}\right)$

$* 3$ : 静岡県沢岡産砂 (密度 $2.62 \mathrm{~g} / \mathrm{cm}^{3} 、$ 吸水率 $1.27 \%$ )

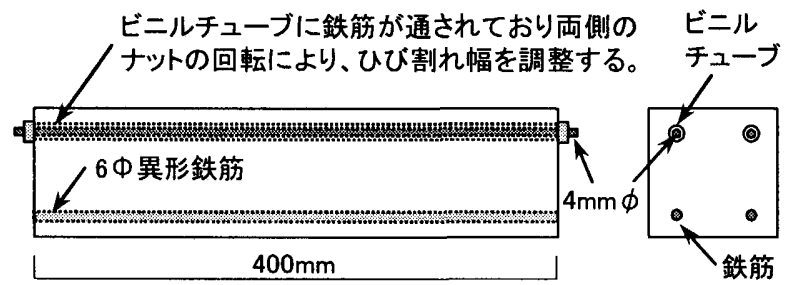

図1 下地として用いたモルタル試験体

表2 試料として用いた塗膜防水層の種類

\begin{tabular}{|c|c|c|c|}
\hline 防水層の種類 & $\begin{array}{c}100 \% \text { モジュラス } \\
\left(\mathrm{N} / \mathrm{mm}^{2}\right)\end{array}$ & $\begin{array}{c}\text { 破断時強度 } \\
\left(\mathrm{N} / \mathrm{mm}^{2}\right)\end{array}$ & $\begin{array}{c}\begin{array}{c}\text { 破断時伸び率 } \\
(\%)\end{array} \\
\end{array}$ \\
\hline $\begin{array}{l}\text { ウレタンゴム系 } \\
\text { 塗膜防水層 }\end{array}$ & 1.5 & 2.6 & 650 \\
\hline $\begin{array}{l}\text { アクリルゴム系 } \\
\text { 塗膜防水層 }\end{array}$ & 2.0 & 2.5 & 300 \\
\hline
\end{tabular}

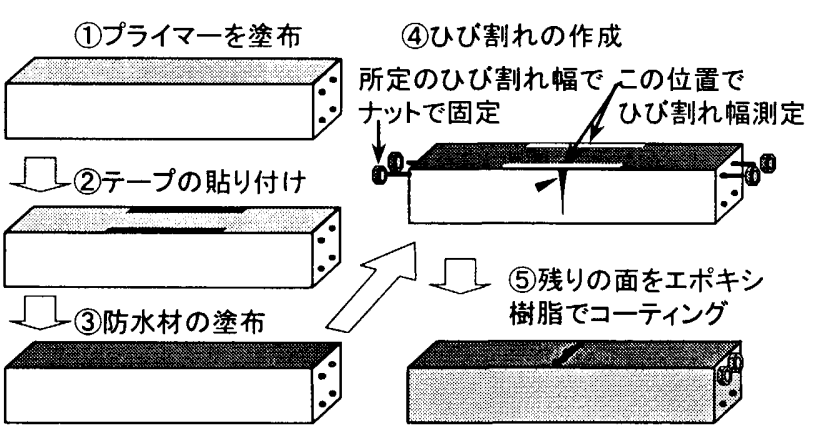

図2 試験体の作成手順

表3 試験体の種類

\begin{tabular}{|c|c|c|c|c|}
\hline \multirow{2}{*}{\multicolumn{2}{|c|}{ 試験体の種類 }} & \multicolumn{3}{|c|}{ ひび割れ幅(mm) } \\
\hline & & 0.5 & 1 & 3 \\
\hline \multicolumn{2}{|c|}{ 塗膜なし } & 0 & 0 & 0 \\
\hline \multirow{4}{*}{$\begin{array}{c}\text { ウレタンゴム } \\
\text { もしくは、 } \\
\text { アクリルゴム } \\
\text { の塗膜厚さ } \\
\text { (mm). }\end{array}$} & 0.3 & 0 & 0 & 0 \\
\hline & 0.5 & 0 & 0 & 0 \\
\hline & 1 & 0 & 0 & 0 \\
\hline & 3 or $2 *$ & $\mathrm{O}$ & $\mathrm{O}$ & 0 \\
\hline
\end{tabular}

○:試験を実施、試験体数は各 2 体

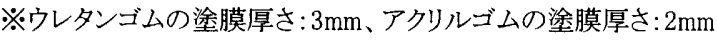

長手方向にコンクリートカッターで途中まで切り込みを入れ、最後 は割裂により内部断面を露出させた。その後、破断面にフェノール フタレイン溶液を噴霧し、炭酸化の状況を調べた。

\section{3 試験結果}

ひび割れ部分の炭酸化状況の一例を写真 1 に示す。またこれをよ り明瞭にするために、2 值化画像処理をして下側に示す。これは、 ひび割れ幅 $3 \mathrm{~mm}$ に対して、防水層が無い場合と、厚さ $1 \mathrm{~mm}$ のウレタ ンゴム系塗膜防水層を施工したものの例である。防水層が施工され 

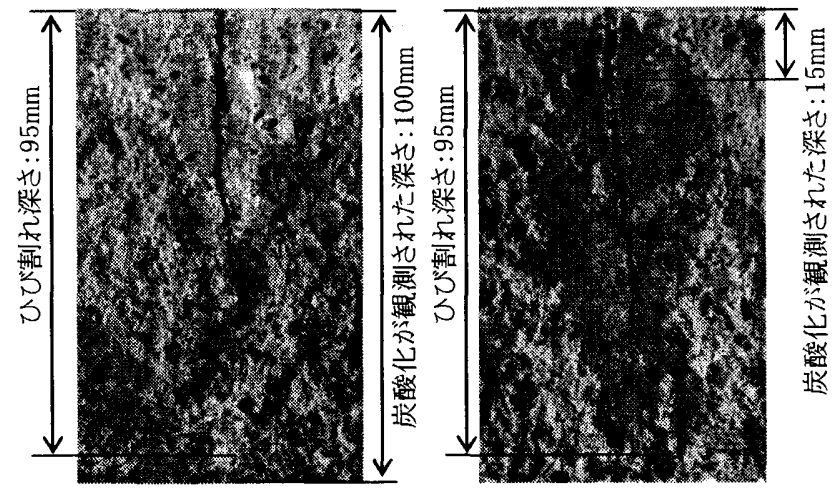

』ひび割れ部の炭酸化進行状況例』

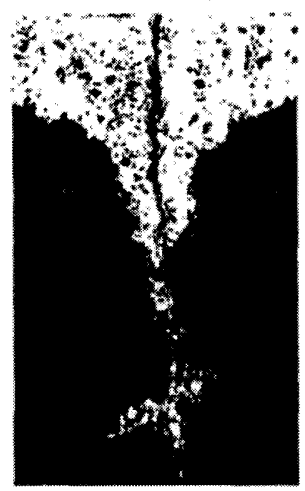

2值化画像·塗膜なし ひび割れ幅 $3 \mathrm{~mm}$ 2 值化画像・ウレタンゴム系塗膜防水層
厚さ $1 \mathrm{~mm}$ ひび割れ幅3mm

写真1 ひび割れ部の炭酸化進行状況例

ていない場合は、従来から指摘されているように、ひび割れに沿っ てその先端近くまでV字形状で炭酸化が進行している。またひび割 れ等のない表層部分も、表面から炭酸化が $20 \mathrm{~mm}$ 程度進行している。

一方、防水層を塗布したものでは、ひび割れのない領域は全く炭 酸化していない。しかし、ひび割れ部分においては、深さ $15 \mathrm{~mm}$ 程 度まで炭酸化の進行が確認された。すなわち叙膜防水層を施工した としても、ひび割れ部分の炭酸化抑止効果は割り引いて評価しなけ ればならないことを示唆するものである。

上記方法によりすべての試験体について、炭酸化進行状況を調べ た結果を図 3 に示す。なお試験結果は 2 体の平均值で表している。

\section{(1) ひび割れ幅の影響}

防水層を施工していない試験体では、ひび割れ幅が小さい場合で も炭酸化がひび割れ先端まで到達している。しかし、防水層が施工 されると炭酸化領域は急激に減少するが、ひび割れ幅が大きい場合 はひび割れに沿ってわずかではあるが内部まで炭酸化が見られる。 これは防水層がひび割れ直上で引っ張られ、厚さが薄くなるため $\mathrm{CO}_{2}$ の遮断性が低下するためと推定される。

\section{(2) 塗膜厚さの影響}

防水層の厚さの影響も顕著であり、膜厚さの薄い場合にはひび割 れに沿って炭酸化が進行している。一方、ウレタンゴム系塗膜防水 層の厚さ $3.0 \mathrm{~mm}$ 、アクリル系防水層の厚さ $2.0 \mathrm{~mm}$ の場合においては、 炭酸化は見られなかった。

（3）防水材料による影響

今回用いた防水材料間には、大きな差は見られなかった。ただ、
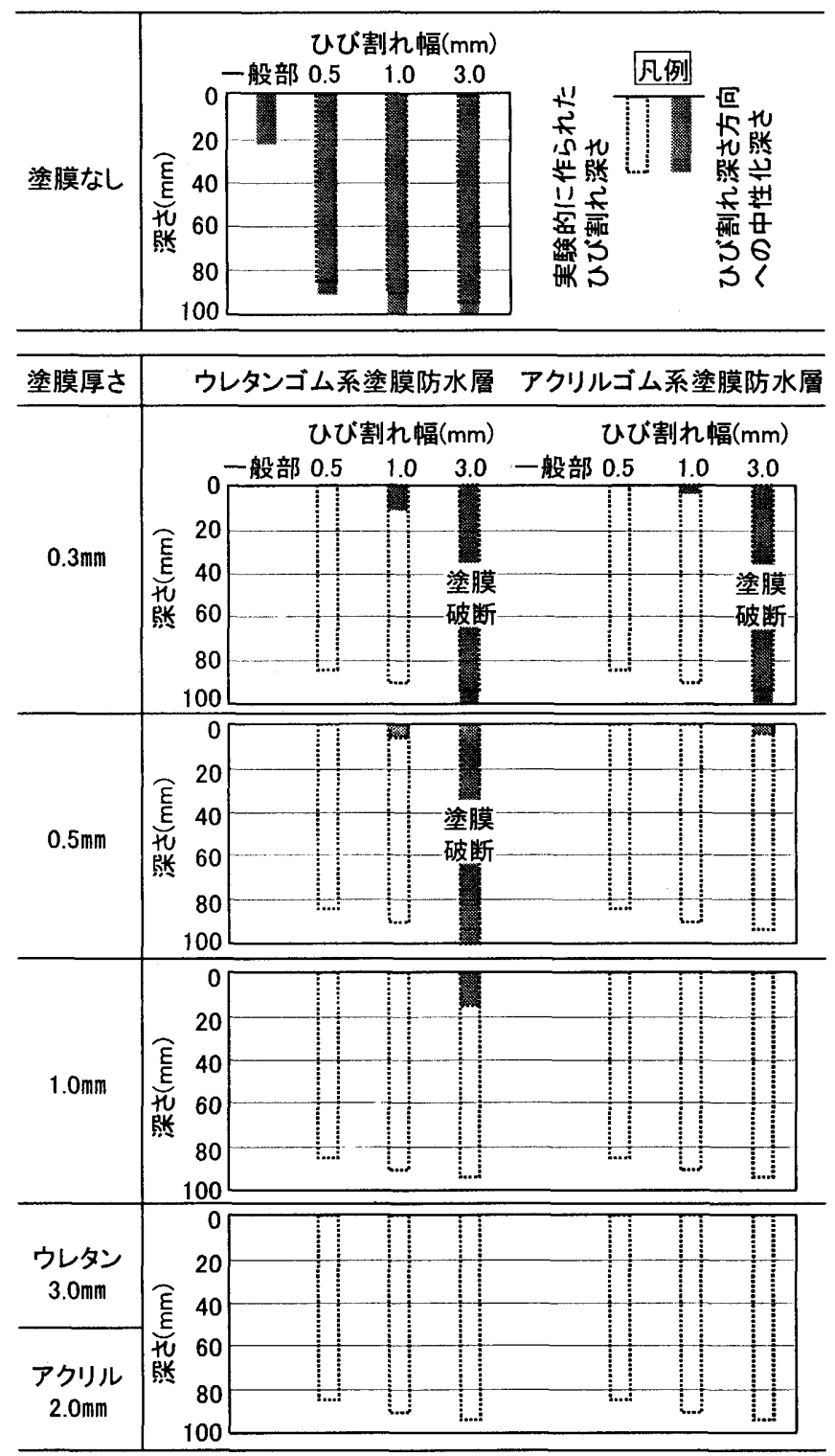

図3 促進中性化試験(期間: 1 年間)による中性化深さ

防水層自身のひび割れ抵抗性には多少差があった。ウレタンゴム系 防水層の方が破断しやすい材料であった。防水層が破断した場合は、 炭酸化に対して全く無防備となり、 $\mathrm{CO}_{2}$ がひび割れ内部にまで入り 込み、炭酸化領域が急速に拡大寸る結果となった。

\section{4. 下地ひび割れ直上部の防水層の炭酸ガス透過性}

ひび割れ直上では防水層皮膜が引き伸ばされて薄くなるため、炭 酸ガスが透過しやすくなり、炭酸化が加速されると推定される。そ のため、防水層皮膜が伸長させられた場合に、どの程度炭酸ガス透 過性が変化するかを調べた。

\section{1 防水層の伸長方法}

（1）下地ひび割れによる防水層の伸長

防水層が下地ひび割れにより引き伸ばされる時、写真 2 のように くびれながら変形する。そのためひび割れ直上の防水層内部の伸長 状態は均一ではない。またその伸長率の直接測定も難しい。そして、 その中央部分では、くびれのため厚さは最も薄くなり、その部分で 炭酸ガス透過性が最も高くなると推定される。ここでは、この最も 
薄くなる部分の透過性を測定する試験方法を工 夫した。

まずひび割れ部分の幅と、防水層のくびれ中 央部分の厚さとの関係を調べた。試験は先の項に て、炭酸化試験に用いた試験体にひび割れを生じ させた時、側面より防水層の厚さの変化を測定し た。測定結果を図 4 に示す。当然のことながら、 ひび割れ幅が拡大するに従ってその部分の厚さ は減少する。

（2）最も薄い部分と等価となる二軸伸長状態

実際のひび割れ直上の防水層は、ひび割れに直 交する方向にのみに変形しており、ひび割れに平 行な方向の変形が拘束されている。いわば、 2 軸

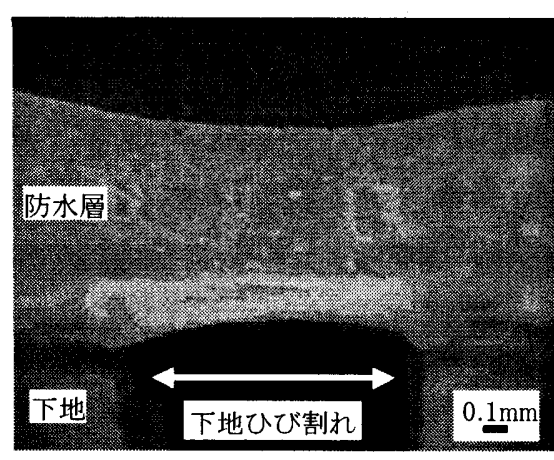

写真2 ひび割れ直上部の防水層の伸長状態

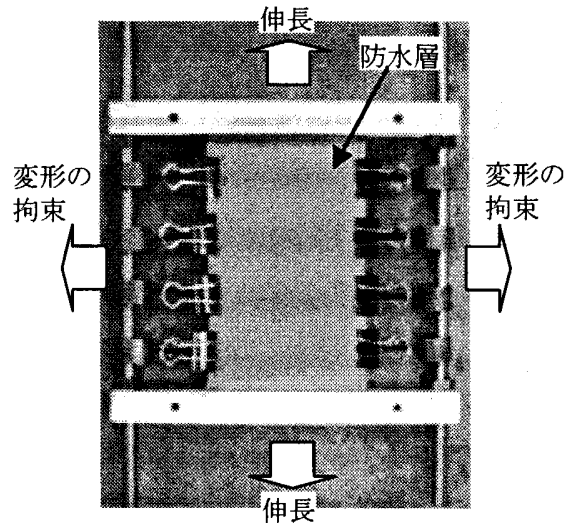

写真3 シート状試験体の 2 軸伸長治具 引張状態にある。そこで、薄くなった厚さと等価となる伸びをシー 卜状試験片に与える方法として、二軸伸長試験を採用した。そのた め、写真 3 に示寸ような防水層試験片の両端をスライド可能なクリ ップで固定し、横方向の変形を拘束し、縦方向に伸長・固定させる ような治具を製作した。なお実際の作業では、応力集中による破断 防止のため、クリップで試験片を挟みこむ部分には補強が必要であ り、端部が一般部分より厚いリブ付き断面のシート状試験片を作成 した。なお試験片厚さは、前項までの試験と同様にウレタンゴム系 塗膜防水層では $0.3 \mathrm{~mm}, 0.5 \mathrm{~mm}, 1 \mathrm{~mm}, 3 \mathrm{~mm}$ 、アクリルゴム系塗膜防水 層では $0.3 \mathrm{~mm}, 0.5 \mathrm{~mm}, 1 \mathrm{~mm}, 2 \mathrm{~mm}$ とした。

（3）伸長率の決定

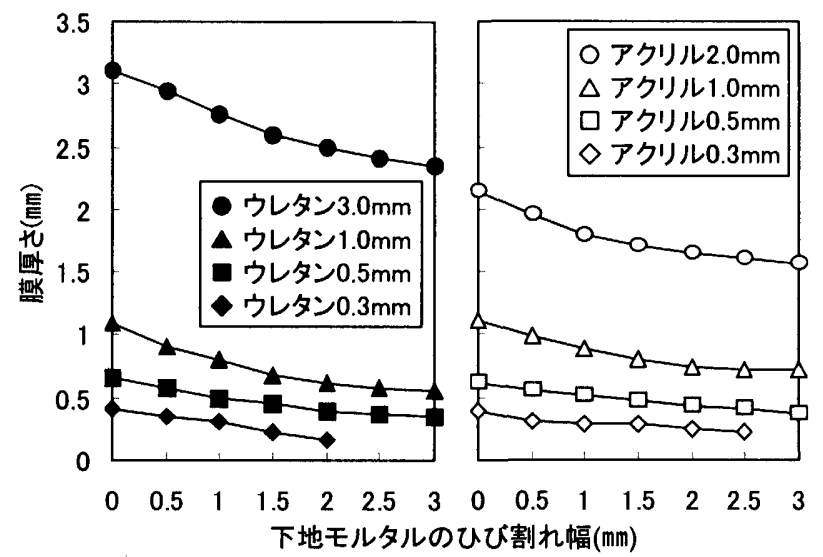

図4 ひび割れ拡大時のひび割れ中央部分の笁膜厚さ

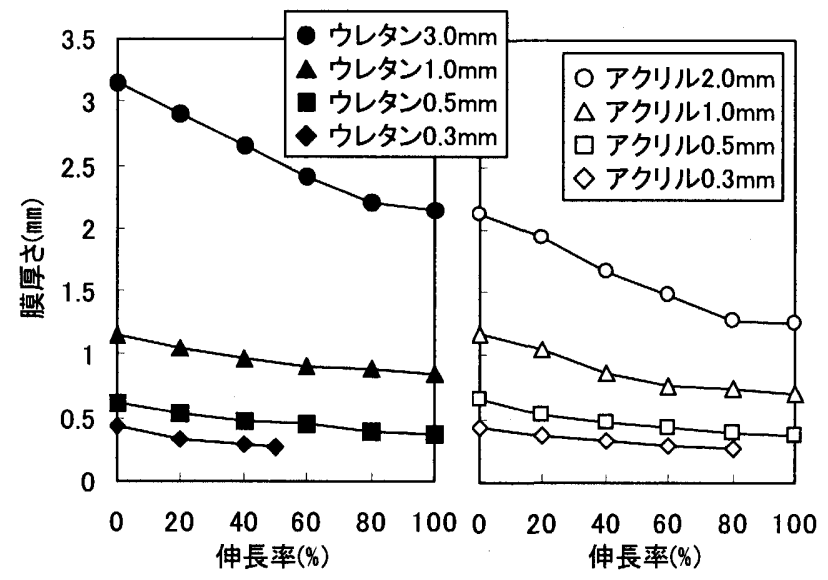

図5 塗膜防水層の厚さと伸長率との関係

まず試験片の伸長率を決定するため、縦方向の伸長によるシート 状試験片の厚さの変化を調べ、図 5 にその関係を示す。この図と図 4 を組み合わせて、ひび割れにより薄くなった防水層厚さと等価と なるシート状試験片の伸長率を調べると、材質、厚さに関わらず下 地ひび割れ幅 $0.5 \mathrm{~mm}$ に相当する伸長率は約 $30 \% 、 1 \mathrm{~mm}$ に対しては約 60\%、3mmに対しては約 100\%であった。

\section{（4）試験方法}

まず各防水層試験片を、各々のひび割れ幅に対応する伸び率まで、 すなわち $30 、 60 、 100 \%$ 伸長させた。次いで、内径 $70 \mathrm{~mm} \phi$ 、内寸高 さ $70 \mathrm{~mm}$ の金属製円筒容器を、伸長した防水層皮膜の片面に置き、 接合部をエポキシ樹脂と、シーリング材でシールした。測定の概要 を図 6 に示す。これ全体を、 $\mathrm{CO}_{2}$ 濃度 $10 \pm 0.5 \%$ 、温度 $20 \pm 2{ }^{\circ} \mathrm{C} 、$ 湿 度 $60 \pm 10 \%$ のチャンバー内に設置した。 $\mathrm{CO}_{2}$ ガスは下側から伸長状 態にある試験片を介して容器内に流入する。その後定期的に、容器 内の $\mathrm{CO}_{2}$ 濃度を写真 4 に示すように、炭酸ガス検知管を、容器上面

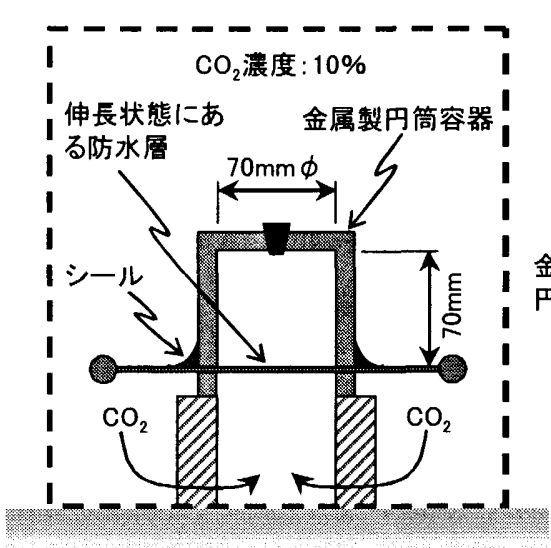

図6 $\mathrm{CO}_{2}$ 透過試験の概要

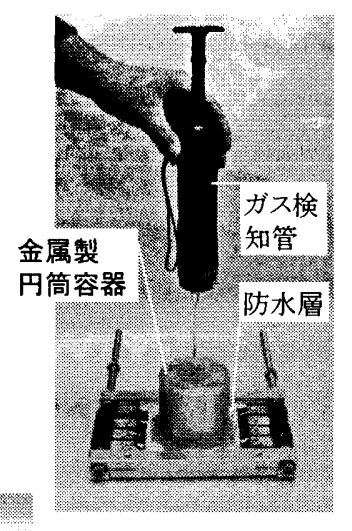

写真4 $\mathrm{CO}_{2}$ の測定
表4透過試験を行った試験体の種類

\begin{tabular}{|c|c|c|c|c|c|}
\hline \multirow[b]{2}{*}{ 防水層の種類 } & \multirow{2}{*}{$\begin{array}{c}\text { 膜厚さ } \\
(\mathrm{mm})\end{array}$} & \multicolumn{4}{|c|}{ 伸長率 $(\%)$} \\
\hline & & $\begin{array}{c}0 \\
\text { (伸長なし) }\end{array}$ & 30 & 60 & 100 \\
\hline \multirow{3}{*}{$\begin{array}{l}\text { ウレタンゴム系 } \\
\text { 塗膜防水層 }\end{array}$} & 0.5 & 0 & 0 & 0 & 0 \\
\hline & 1 & 0 & 0 & 0 & 0 \\
\hline & 3 & 0 & 0 & 0 & 0 \\
\hline \multirow{3}{*}{$\begin{array}{c}\text { アクリルゴム系 } \\
\text { 塗膜防水層 }\end{array}$} & 0.5 & 0 & 0 & 0 & 0 \\
\hline & 1 & 0 & 0 & 0 & 0 \\
\hline & 2 & 0 & 0 & 0 & 0 \\
\hline
\end{tabular}

$\bigcirc$ :試験を実施、試験体数:各 2 体 

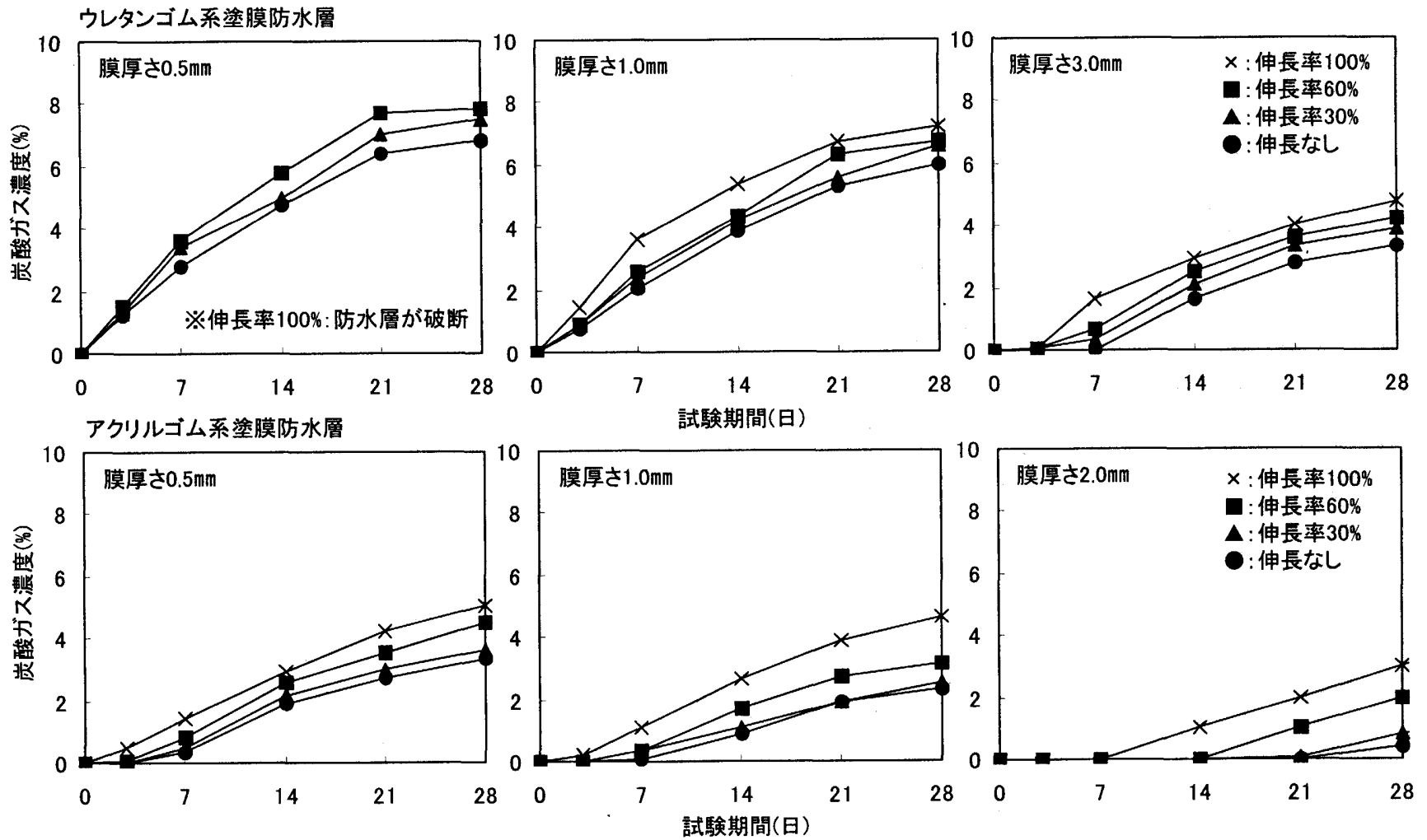

図7 カップ内の防水層を透過した炭酸ガス量の測定結果

の測定孔から内部に差込み、 $50 \mathrm{ml}$ 程度を吸引採取し、測定した。 4.3 測定結果

炭酸ガス濃度の測定結果を図 7 に示す。時間の経過と共に容器内 の炭酸ガス濃度は増加する。その増加の割合は初期に著しいが、次 第に緩慢となる。この結果をもとに防水層の見かけの透過度を式 （1）により計算した。なお、ここで見かけの透過度としたのは、防 水層が伸長されており、無伸長状態で定義される透過度と区別する ためである。また、この見かけの透過度は単位期間・単位面積あた りの各透過度を平均した値である。

$$
\frac{\partial C}{\partial t}=D_{x} \cdot \frac{\partial^{2} C}{\partial x^{2}}+D_{y} \cdot \frac{\partial^{2} C}{\partial y^{2}}-k \cdot C \cdot C a \quad \cdots \quad \text { (2) }
$$$$
\text { ここで、 }
$$$$
\mathrm{C}: \mathrm{CO}_{2} \text { 濃度 }
$$$$
\Delta t \quad \text { : 単位時間 }
$$$$
D x 、 D y ： \text { 下地モルタルの拡散係数 }
$$$$
\begin{aligned}
& \partial x, \partial y: \text { 要素寸法 } \\
& k
\end{aligned}
$$$$
\mathrm{Ca} \quad \text { : Ca }(\mathrm{OH})_{2} \text { 濃度とする。 }
$$

$$
\begin{aligned}
P=Q / C_{l, 2} & \\
\text { ここで、 } P & : \text { 見かけの透過度 }(\mathrm{mm} / \mathrm{day}) \\
Q & : \mathrm{CO}_{2} \text { の透過量 }\left(\mathrm{mm}^{3} / \mathrm{day} \cdot \mathrm{mm}^{2}\right) \\
C_{l, 2} & : \mathrm{CO}_{2} \text { の濃度差 }\left(\mathrm{mm}^{3} / \mathrm{mm}^{3}\right)
\end{aligned}
$$

この式により得られた見かけの透過度を図 8 に示す。伸長率の影 響は顕著であり、伸長の程度が大きくなるに従って、見かけの透過 度は大きくなる。これは防水層が引つ張られることにより、防水層 内部の微小欠陥、気泡等が伸長され、ガス透過性が高まるためと思 われる。

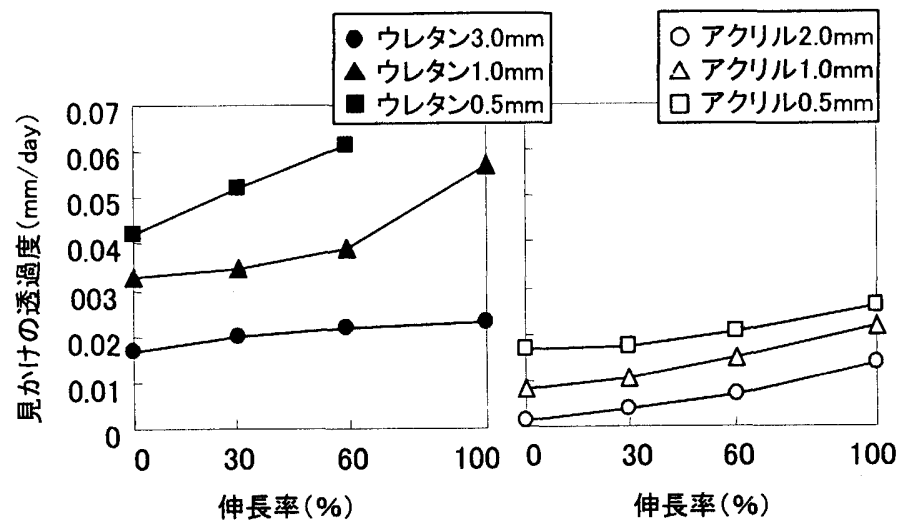

図8防水層の見かけの透過度と伸長率

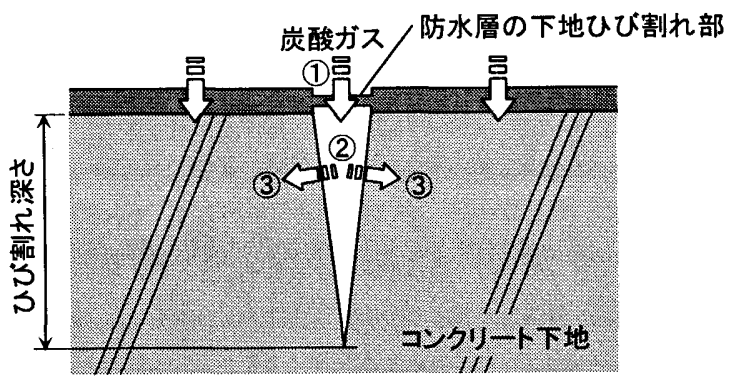

図9防水層下のコンクリート下地ひび割れ部の炭酸化進行の概念図

\section{5. 防水層下の下地ひひ割れ部分の炭酸化シミュレーション}

5.1 伸長状態にある防水層および下地ひび割れ部分のモデル化とシ ミュレーションの考え方

防水層が施工されても炭酸化がひび割れ内部まで進行するとい うここまでの実験の結果は、ひび割れ直上の防水層が大きく引つ張 


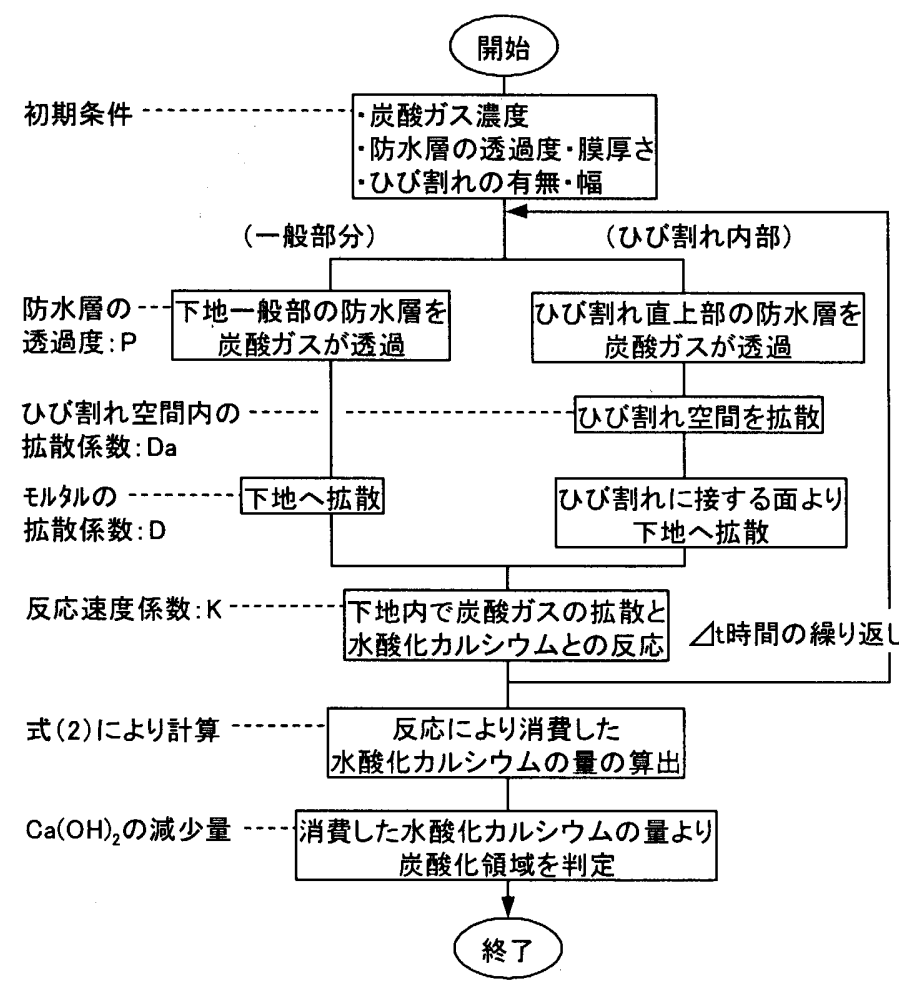

図10 シミュレーションの流れ

られ、炭酸ガス透過量が増加するためと推定される。この状態を想 定して、炭酸化シミュレーションを行った。

そのため実際のひび割れ部分の防水層を図 9 に示すようなモデ ルに簡略化した。そして、炭酸ガス浸入は次の 3 段階を経ると考え た。すなわち、(1)防水層皮膜を炭酸ガスが拡散し透過する過程、(2) ひび割れ空間内で炭酸ガスと空気とが相互拡散する過程、(3)それが コンクリート内部に拡散して行く過程である。この計算フローを図 10 に示す。

(1) 防水層の透過度

まず防水層皮膜を透過して炭酸ガスが下地部分および、ひびわれ 部分へと透過する過程には前項の測定による見かけの透過度を使 用した。

(2)ひび割れ空間内の拡散係数 ひび割れ空間内の拡散係数 は、ある梁さ方向の地点にお けるひび割れ幅ごとに異なる と予想される。このため、ひ び割れ表面から先端までのひ び割れ幅を一定とした時の試 験体を作製して、その平行な ひび割れ幅を変数とした透過 試験を行なった。そして、そ の結果をシミュレーションモ デルに適用することとした。

試験には直径 $10 \mathrm{~cm} \times$ 高さ

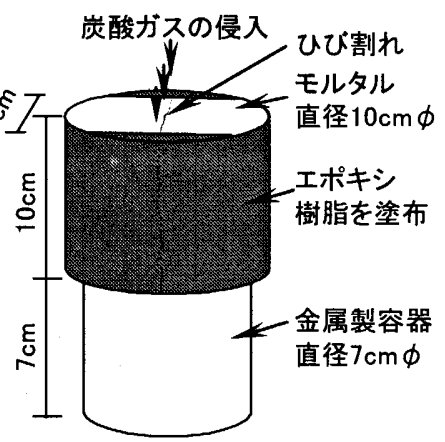

図11 ひび割れ部の炭酸ガスの 移動速度測定

$10 \mathrm{~cm}$ のモルタル円柱試験体を 1 ケ月間 封緘養生した後、割裂し、 試験槽内で十分に炭酸化させたものを使用した。この割裂したモル タルが $0.5 \mathrm{~mm} 、 1.0 \mathrm{~mm} 、 3.0 \mathrm{~mm}$ のひび割れ間隔になるよう平行に固定

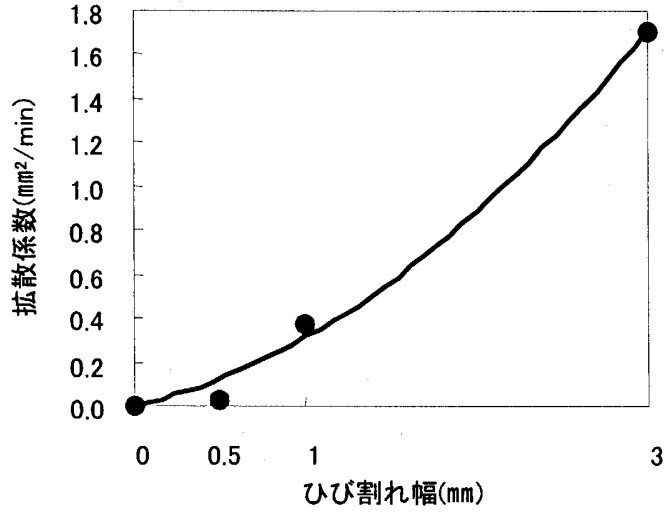

図12 ひび割れ部の炭酸ガスの拡散係数

し、片面に容器を取り付け、ひび割れを通過して容器内部に侵入し た炭酸ガスの量を定期的にガス検知管により測定した。図 12 に測 定結果より求めたひび割れ部の炭酸ガスの拡散係数を示す。

(3) モルタル内部の拡散係数

下地モルタル部分の炭酸ガスの拡散係数は、既往の文献 ${ }^{91}$ を参考 にモルタルの促進中性化試験結果により求めた值である $3 \mathrm{~mm}^{2} / \mathrm{day}$ を使用した。なお、シミュレーションでは、ひび割れ深さ方向及び ひび割れ幅の方向に炭酸ガスが拡散するモデルとした。

(4) 炭酸化反応速度係数について

炭酸化反応過程は、炭酸ガスと水酸化カルシウムの反応と仮定し、 式(2)を用いて水酸化カルシウムの減少量を求めた。なお、炭酸ガ スとモルタル中の水酸化カルシウムとの反応速度係数は既往の文 献 ${ }^{10)}$ より $5 \times 10^{6} /$ dayとした。

\section{2 解析モデル}

図 13 に下地ひび割れ部の解析モデルを示す。解析モデルは 2 次 元の対称モデルとし、式(2)を用いて差分法により計算を行なった。 境界条件に関して、防水層面については防水層の塗膜厚さを前述で 測定した見かけの透過度に置き換え、ひび割れ幅については、 5.1 (2)のひび割れ空間内の拡散係数に置き換えることとした。モル

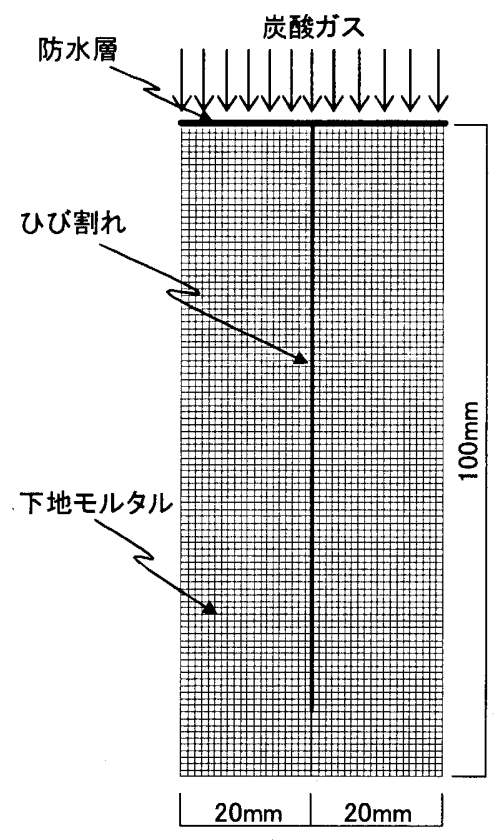

図13 下地ひび割れ部のモデル化 (要素寸法: $1 \mathrm{~mm} \times 1 \mathrm{~mm}$ ) 


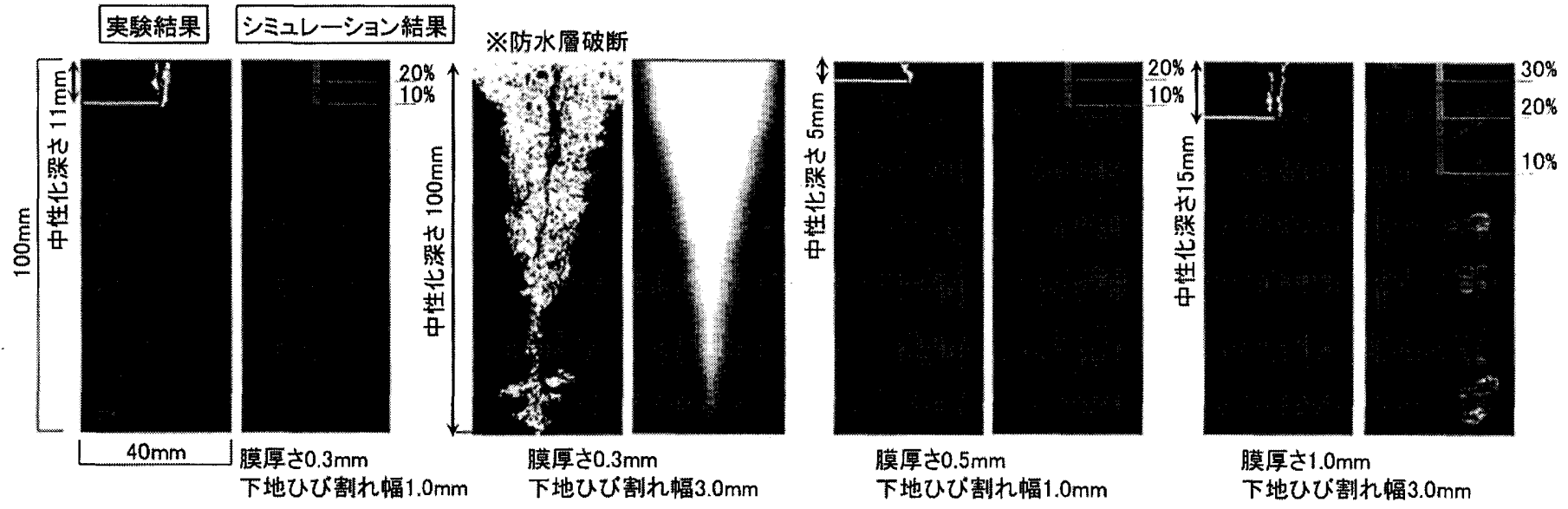

図14 促進中性化試験結果とシミュレーション結果の比較例(ウレタンゴム系塗膜防水層の場合)

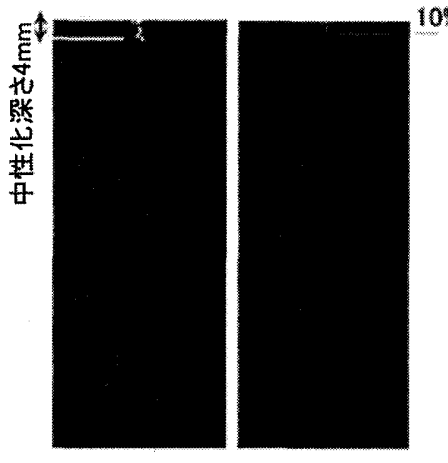

膜厚さ $0.3 \mathrm{~mm}$ 下地ひび割れ幅 $1.0 \mathrm{~mm}$

図15促進中性化試験結果とシミュレ一ション結果の比較例 （アクリルゴム系塗膜防水層の場合）

タル部の要素の大きさは縌横 $1.0 \mathrm{~mm}$ とした。計算の条件は促進中性 化試験と同じ炭酸ガス濃度 $10 \%$ とし、暴露期間は 1 年間とした。な お、要素の大きさによる解の収束性は別途確認した。

5.3 シミュレーション結果

促進中性化試験で炭酸化が観察された試験体について、シミュレ ーション結果を、下地モルタル中の水酸化カルシウムが炭酸ガスと 反応して減少した割合として表し、グレースケールで表示した。な お、実験結果は 2 值化して結果を示している。図 14 にウレタンゴ ム系塗膜防水層について、図 15 にアクリルゴム系塗膜防水層につ いて比較をした結果を示す。いずれもひび割れ内部が炭酸化してい る状態が示されている。ただ解析モデルの分割要素の大きさは $1 \mathrm{~mm}$ $\times 1 \mathrm{~mm}$ であり、各々の要素内では実際には濃度勾配をもつものが平 均化された值としてしか計算されていないため、相関性については 大まかにしか議論できないが、概ね要素の平均炭酸化率 10～20\%程 度を闇值とした場合と実験結果とは良く整合しているように思わ れる。

これをみると防水層が施工されているとひび割れのない部分は 全く炭酸化が見られていない。しかしひび割れ部分では防水層があ るにも係わらず炭酸化が生じている。これはひび割れ部で皮膜が伸 長させられ、ガス遮断性能が低下し、ひび割れ内部に炭酸ガスの侵 入を許容し、モルタル内部の炭酸化が生じたとするここでの考え方 の妥当性を示していると考えられる。

5.4 ひび割れ部分の防水層の炭酸化抑制に関する考察

防水層等のコンクリート表面保護皮膜の存在は重要である。そし

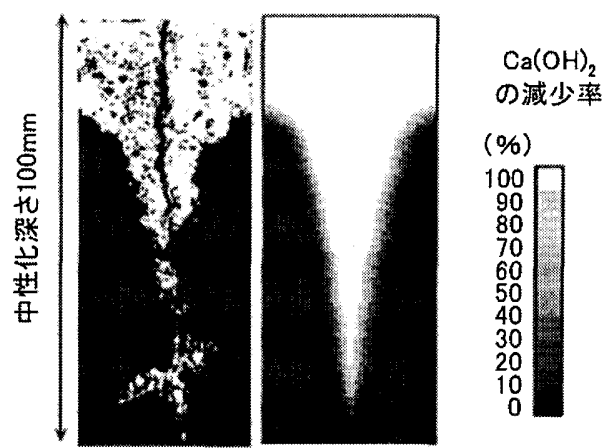

防水雁なし

下地ひび割れ幅 $3.0 \mathrm{~mm}$

図16 促進中性化試験結果とシミュレーション結果の比較例 (塗膜防水層なしの場合)

て下地がひび割れても、ひび割れ内部に面するモルタル部分の炭酸 化はかなり抑制される。しかし、伸長状態にある皮膜の炭酸ガス遮 断性能は低下寸るため、 $1 \mathrm{~mm}$ 程度のひび割れを予想すると防水層の 厚さは $1 \mathrm{~mm}$ 以上は必要であることが、実験およびシミュレーション 結果より考察される。

実際に防水層皮膜の破断があると、図 14 に示すように炭酸ガス の侵入が顕著になり、ひび割れの奥哚くまで炭酸化領域は拡大する。 もち万ん防水層で全く保護されていない場合は、同じく図 16 に示 すように、ひび割れ部分のみならず表面からも炭酸化が生じるが、 皮膜破断の場合も、それに匹敵するくらいの領域の炭酸化が生じて いる。これら皮膜の下地ひび割れ抵抗性は皮膜厚さが直接関係して いるため、この観点からも、充分な厚さの必要性が指摘される。

\section{6. 結論}

塗膜防水層下の下地モルタルひび割れ部分の炭酸化について検 討した本研究の結論は、以下の通りである。

（1）下地にひび割れのない部分については、防水層の存在が炭酸化 を抑制するという従来の実験結果を確認した。

（2）防水層があっても下地の炭酸化を完全に抑止するものではなく、 下地のひび割れ幅が大きい場合には、ひび割れに沿って炭酸化 することを明らかにした。

（3）抑制効果低下の原因は、2 軸伸長による炭酸ガス透過試験によ り、防水層が伸長されると、炭酸ガス遮断効果が低下するため であることを実験的に示した。 
（4）塗膜系材料で、コンクリートひび割れ部における炭酸化抑制効 果を期待するには、十分な塗膜厚さが必要であることを示した。

（5）ひび割れ直上部分の防水層の伸長を考慮した簡便なモデルを用 いて炭酸化シミュレーションを行い、実験值と比較し、その有 用性を示すと共に、ひひ割れ部分の炭酸化現象の評価を可能と した。

\section{参考文献}

1）阿部保彦：ひび割れ幅がコンクリートの中性化深さに及ぼす影響に 関する文献調查報告 コンクリート構造物のリハビリテーション に関するシンポジウム論文集 1998.10

2）魚本健人：コンクリート診断学入門 構造物の劣化対象 2004.9.30

3）塚原絵万: ひび割れを有するコンクリート中の鉄筋腐食に関する基 脴的研究 コンクリート工学論文集 $2000.1 \mathrm{pp} 75,84$

4）長谷川拓哉：仕上材の鉄筋コンクリート躯体中性化抑制効果に関寸 る研究 2003.11
5）本橋健司、桝田佳寛：コンクリート仕上げ材料の中性化抑制性能評 価における熱重量分析の応用; 日本建築学会構造系論文報告集、第 579 号、pp15.21,2004.5

6）長谷川拓哉：モデル建物の 11 年屋外暴露試験結果に基づく表面仕 上げ材の中性化に対する保護効果; 日本建築学会構造系論文報告集、 第 555 号、pp37.43,2002.5

7）福島敏夫: 表面仕上げ材のコンクリートの中性化抑制効果の定量的 評価 ; セメント・コンクリート論文集、No. 44, pp. 448 - 453, 1990

8）福島敏夫：コンクリートの中性化進行の理論的予測法上数値解析 その 1 鉄筋コンクリート構造物外壁の耐久性予測法に関する研 究 ; 日本建築学会構造系論文報告集、第 428 号、pp1. $15,1991.8$

9）長井宏憲、兼松学、野口貴文、友澤史紀 : 遺伝的アルゴリズムによ る RC 構造物の補修・改修最適化問題に関する研究 pp. 457-462, ユ ンクリート工学年次論文集 Vol.22. No. 1.2000

10）桝田佳寛、棚野博之：コンクリートの中性化進行予測モデル、コン クリート工学論文集、Vol. 2. No. 1. 1991, 1

（2006年 2 月 10 日原稿受理， 2006 年 5 月 2 日採用決定） 